\title{
Democratic Centralism and Administration in China
}

\author{
Sarah Biddulph ${ }^{1}$
}

\section{INTRODUCTION}

The decision issued by the fourth plenary session of the 18th Central Committee of the Chinese Communist Party (CCP, or Party) in 2014 on Some Major Questions in Comprehensively Promoting Governing the Country According to Law (the 'Fourth Plenum Decision') reiterated the Party's determination to build a 'socialist rule of law system with Chinese characteristics' ${ }^{2}$ What does this proclamation of the 'socialist' nature of China's version of rule of law mean, if anything? Development of a notion of socialist rule of law in China has included many apparently competing and often mutually inconsistent narratives and trends. So, in searching for indicia of socialism in China's legal system it is necessary at the outset to acknowledge that what we identify as socialist may be overlaid with other important influences, including at least China's long history of centralised, bureaucratic governance, Maoist forms of 'adaptive' governance ${ }^{3}$ and Western ideological, legal and institutional imports, outside of Marxism-Leninism. In fact, what the Chinese party-state labels 'socialist' has already departed from the original ideals of European socialists. This chapter does not engage in a critique of whether Chinese versions of socialism are really 'socialist'. Instead it examines the influence on China's legal system of democratic centralism, often attributed to Lenin, but more significantly for this book project firmly embraced by the party-state as a core element of 'Chinese socialism'.

Having asserted the centrality to governance of 'socialist rule of law with Chinese characteristics', it is timely to consider what are its distinctive characteristics and how these might assist us to better understand the trajectory of Chinese legal reforms. Two preliminary issues of context help explain the importance of understanding the basic parameters of China's legal system reforms. The first is the framework for analysis of Chinese legal development-can it usefully be seen as a form of either transition or incomplete transition? The second is the potential international impact of the Chinese model of rule of law (if one exists).

In respect of the first issue, many analyses of the development of the rule of law in China

\footnotetext{
${ }^{1}$ This research was supported by a grant from the Australian Research Council [FT130100412].

${ }^{2}$ English translation available at https://chinacopyrightandmedia.wordpress.com/2014/10/28/ccp-centralcommittee-decision-concerning-some-major-questions-in-comprehensively-moving-governing-the-countryaccording-to-the-law-forward/.

${ }^{3}$ That is the capacity to respond in diverse ways to 'shocks and disturbances' in a way that furthers the resilience of the system. See discussion in Sebastian Heilmann and Elizabeth Perry, eds., Mao's Invisible Hand: The Political Foundations of Adaptive Governance in China (Cambridge (Mass) and London: Harvard University Press, 2011).
} 
imagine that, as China's economy develops, we will gradually see development and broadening of law as a mode of governance and the strengthening of legal institutions. It is a vision that has China 'marching toward the rule of law'. ${ }^{4}$ Will economic and legal reforms result in some form of convergence with a procedural or 'thin' version of the rule of law, if not a liberal democratic-inspired normative version of rule of law? Increasingly, this possibility seems unlikely. Many now argue that the legal system we see operating in China cannot be explained away as one of 'incomplete transition'. Landry, Tong and Shen note that key features of the Leninist party-state remain-one of which is political control over legal institutions. ${ }^{-5}$ They argue that we can't characterise unexpected features of the legal system as 'transitional because we see it as a temporary out of equilibrium phenomenon'.6. These comments invite us to question whether what might appear to be an anomaly in China's legal development is in fact an anomaly, or if it is actually indicative of a more stable, permanent feature of the legal system - though one that we had not expected to see. To be clear, I am not making an argument that the Chinese system is unique in this. The varieties of capitalism literature point out the diversity of legal systems, and the ways the overall structure of the legal system impacts on the nature of legal reform and legal responses to crises. ${ }^{7}$ And China is not the only authoritarian state that is developing a version of rule of law that suits and supports authoritarian modes of governance. China is one example among a number of authoritarian states establishing a legal edifice for governance that might also produce something unexpected.

In respect of the second issue, the Fourth Plenum Decision and what it says about rule of law in China also needs to be read in the context of a broader question about the significance of China's push back against so-called 'Western' ideas, including liberal democratic visions of the rule of law and the relationship between citizen and state that that vision instantiates. There is increasing worry that rising (socialist or post-socialist) authoritarian powers, with China as one of those at the forefront, are acting to entrench counter-norms to liberal democracy, rule of law and the universal values they represent. At the international level, this can be seen in areas such as 'privileging state security, civilizational diversity (non-interference in domestic affairs) and traditional values' ${ }^{8}$ At the domestic level, these include prioritisation of the interests of the party-state and social order at the expense of individual rights. ${ }^{9}$ Party leadership has explicitly rejected a number of core elements of a liberal democratic notion of rule of law-separation of

\footnotetext{
${ }^{4}$ Randall Peerenboom, China's Long March toward Rule of Law (Cambridge: Cambridge University Press, 2002).

${ }^{5}$ Pierre Landry, Yanqi Tong, and Mingming Shen, "Introduction: Markets, Courts and Leninism," The China Review 9 , no. 1 (2009).

${ }^{6}$ Ibid., 2.

${ }^{7}$ Curtis Milhaupt and Katarina Pistor, Law and Capitalism: What Corporate Crises Reveal About Legal Systems and Economic Development around the World (Chicago: Chicago University Press, 2008).

${ }^{8}$ Alexander Cooley, "Authoritarianism Goes Global: Countering Democratic Norms," Journal of Democracy 26, no. 3 (2015).

${ }^{9}$ Sarah Biddulph, The Stability Imperative: Human Rights and Law in China (Vancouver: UBC Press, 2015).
} 
powers, independence of the judiciary and constitutionalism among the most obvious. ${ }^{10}$. So, behind our inquiry into socialist characteristics of China's version of the rule of law lurks a question of whether these developments present a challenge or establish a counternorm to the liberal democratic notion of rule of law? This chapter raises, but leaves open, this broader question.

In interrogating the socialist nature of Chinese rule of law, this chapter focuses on a core ideological and institutional principle of party and state: democratic centralism. It also notes that a dominant form of legality is the political-administrative orientation of governance. It explores the nature and extent of the role that these elements of ideology and form continue to play in structuring the legal system and influencing modes of governance more broadly.

Nicholson and Pham's chapter in this volume examines the impact of democratic centralism on the institutional organisation of courts and the procuratorate in Vietnam. Rather than adopt a similar institutional focus for analysis, or address the question as one of ideology, this chapter seeks to explore the practical impact of democratic centralist arrangements of power and policy making on governance-the ways in which power is exercised. It does not make a general claim about governance as a whole, but seeks to identify how the organisational aspects of democratic centralism are at play in shaping certain areas of administration. It uses as its example campaign-style enforcement (yundongshi zhili) - specifically, the ongoing campaigns to redress the systemic problem of wage arrears.

The main argument of this chapter is that there is ready resort to the campaign form as a way to redress perceived crises arising from failures in decentralised forms of regulation and enforcement. It asserts that campaign-style enforcement depends heavily on the organisational principles of democratic centralism, with an emphasis on centralisation of analysis and strategy, target setting and reporting back. Campaigns also reflect what Tay and Kamenka have labelled the 'bureaucratic-administrative' character of governance, and have a strong centrally planned flavour. ${ }^{11}$ Campaign-style enforcement punctuates regular decentralised enforcement and is so commonly used that I argue it could be seen as a regular feature of governance, rather than an exception to ordinary day-to-day

\footnotetext{
${ }^{10}$ One instance is the 'Seven Don't Mentions' set out in the Communique on the Current State of the Ideological Sphere issued by the General Office of the Central Party Committee in May 2013 prohibiting discussion of: universal values, press freedom, civil society, civic rights, historical mistakes of the Communist Party, elite cronyism and judicial independence. Anne Henochowicz, 'Words of the Week: Seven Don't Mentions', China Digital Times, 23 April 2015, available at www.chinadigitaltimes/2015/04/words-of-the-week-seven-don'tmentions/. Another is the speech given by the Chief Justice of the Supreme People's Court Zhou Qiang in January 2017 in which he warned against falling into the Western ideological traps of constitutional democracy, separation of powers and judicial independence. Michael Forsythe, 'China's Chief Justice Rejects an Independent Judiciary, and Reformers Wince', New York Times, 18 January 2017, available at www.nytimes.com/2017/01/18/world/asia/china-chief-justice-courts-zhou-qiang-html? $r=0$. ${ }^{11}$ Alice Tay and Eugene Kamenka, "Marxism, Socialism and the Theory of Law," Columbia Journal of Transnational Law 23 (1984-1985).
} 
administration.

After giving a brief account of the concepts of democratic centralism as it relates to governance in contemporary China, I will develop my argument through a detailed discussion of law enforcement campaigns. Throughout, I raise questions about the organisation and form of campaigns, which rely on central organisation and control, mobilisation and propaganda. All in turn, I argue, reflect the basic principles of democratic centralism. In particular, I will focus on campaigns to address non-payment of wages-the 2004-2007 Wages Campaign and the annual wages campaigns conducted since. ${ }^{12}$

\section{DEMOCRATIC CENTRALISM}

\subsection{Historical Evolution}

While the focus of the discussion in this chapter is on the CCP, it is relevant to note that the embrace of Leninist principles of party organisation was not unique to the Communists. From the early 1920s, both the Nationalist and the Communist Parties adopted democratic centralism as their fundamental organisational principle, and as the ideological basis of governance. For both, the Leninist notion of strong centralised governance exercised by a political elite was key. ${ }^{-13}$

The CCP embraced democratic centralism in its 1928 and 1945 Constitutions. ${ }^{-14}$ Identification of democratic centralism as the fundamental principle of both Party organisation and the system of government in China is affirmed in 1940 in Mao Zedong's essay, On New Democracy, ${ }^{-15}$ and reiterated in 1945 in his report On Coalition Government. ${ }^{-16}$ In his essay On New Democracy, Mao drew a distinction between the 'state system' (guoti) and the system of government (zhengti). The state system was defined as the 'dictatorship of all the revolutionary classes'; defining the status of social classes within the state. The system of government is the way power is organised and exerciseddemocratic centralism.

In a speech made on 1 February 1942, Mao Zedong criticised sectarian tendencies within the Party, saying:

They do not understand the Party's system of democratic centralism; they do not realise that

\footnotetext{
${ }^{12}$ My discussion of the wages campaign draws on the account of the campaign set out in Sarah Biddulph, Sean Cooney, and Ying Zhu, "Rule of Law with Chinese Characteristics: The Role of Campaigns in Law-Making," Law \& Policy 34, no. 4 (2012). In discussing this campaign, I am primarily interested in the form of the campaign- as a mode of governance and what it might reveal about the socialist characteristics of the Chinese version of the rule of law. In our article we focused instead on questions about the impact of the campaign on law reform and the iterative cycle of law making, interpretation and implementation.

${ }^{13}$ In respect of the Guomindang (or Kuomintang KMT) see discussion in Yangsun Chou and Andrew Nathan, "Democratizing Tradition in Taiwan," Asian Survey 27, no. 3 (1987).

${ }^{14}$ See discussion in Douglas Howland, "Popular Sovereignty and Democratic Centralism in the People's Republic of China "Social Text 30, no. 1 (2012).

${ }^{15}$ At https://www.marxists.org/reference/archive/mao/selected-works/volume-2/mswv2 26.htm

${ }^{16}$ At https://www.marxists.org/reference/archive/mao/selected-works/volume-3/mswv3 25.htm
} 
the Communist Party not only needs democracy but needs centralisation even more. They forget the system of democratic centralism in which the minority is subordinate to the majority, the lower level to the higher level, the part to the whole and the entire membership to the Central Committee. ${ }^{17}$

The Party's ideological platform (as a vanguard party) is that it represents the overall interests of the people and society. Democratic centralism is seen as the way in which integration between Party leadership, the position of the people as 'masters of the country' and (since the beginning of the reform era in 1978) the rule of law can be achieved. A core aspect of democratic centralism 'is that objective, scientific judgements can be made by Party leaders based on evidence gathered through the democratic process', but also that the political leadership is not bound to follow popular inputs. ${ }^{18}$ In theory, there should be a correct balance between democracy and centralism. This theory holds that democracy cannot exist without centralism, and that democracy without centralism will lead to chaos.

Mao Zedong emphasised the mass line (qunzong lüxian) as complementary to democratic centralism, as an aspect of democracy. It was a way of ensuring the Party's close links and responsiveness to the concerns of the people. It operated by incorporating popular views in decision-making processes and then propagating these ideas and decisions back to the people. However, this process was not designed merely to act as a reflection of the popular will. It was intended to be a mechanism by which the Party guided the consciousness of the people so that they embraced these policies and decisions 'as their own'-19. (even if the policies did not ultimately reflect popular inputs), and as a way to mobilise them to action. ${ }^{20}$ Throughout the history of the People's Republic of China (PRC), the balance between centralism and democracy has changed, often at the expense of democracy. The form that democracy has taken has also changed alongside the shifting politics of the time.

In terms of the relationship between the people and the Party centre, Mao's view was that participation should be allowed, though managed and controlled by the centre. In his speech On the Ten Major Relationships in 1956, Mao applied a similar principle to the relationship between the centre and localities, under which localities were to be consulted, allowed a degree of autonomy and permitted to take some initiatives, although this was tightly controlled by the centre and for the purpose of building a 'powerful socialist country'. ${ }^{21}$ McFarquhar and Fairbank point out, however, that Mao did not place great weight on giving democracy an institutional form, a tendency that escalated as Mao

\footnotetext{
${ }^{17}$ Mao Zedong 'Rectify the Party's Style of Work', in Selected Works of Mao Tse-tung (Peking: Foreign Languages Press, 1967), vol. III, pp. 35-51.

${ }^{18}$ Stephen Angle, "Decent Democratic Centralism," Political theory 33 (2005).

${ }^{19}$ Mao Zedong, 'Some Questions Concerning Methods of Leadership', speech given on 1 June 1943, reproduced in Mao Zedong, Selected Works of Mao Tse-tung, p. 119, excepted in Roderick McFarquhar and John K Fairbank, eds., Cambridge History of China, vol. 15 Part 2 (Cambridge: Cambridge University Press, 1991). p. 3.

20 lbid., pp. 3-6.

${ }^{21}$ Ibid., p. 9. The full text of the speech is available at www.marxists.org/reference/archive/mao/selectedworks/volume-5/mswv5 51.htm
} 
became increasingly radical from the late $1950 \mathrm{~s}^{22}$ The mass line increasingly became a mode of mass mobilisation and a way of waging continuous revolution. Howland argues that mass mobilisation, with the most extreme example being the Great Leap Forward, served to strengthen central control by the Party and diverted attention away from the needs and ideas of people at the grassroots. 23 .

\subsection{Ideology in the Reform Era (after 1978)}

After the end of the Cultural Revolution, Deng Xiaoping reaffirmed the centrality of democratic centralism as the fundamental organisational principle and ideological basis of governance of both Party and state. In December 1978, he famously argued that the problem of governance had not been excessive democracy, but centralism at the expense of democracy.

One important condition for getting people to emancipate their minds and use their heads is genuine practice of the proletarian system of democratic centralism. We need unified and centralised leadership, but centralism can be correct only when there is a full measure of democracy. At present, we must lay particular stress on democracy, because for quite a long time democratic centralism was not genuinely practised: centralism was divorced from democracy and there was too little democracy. ${ }^{24}$

Democracy may be strengthened, he argued, by hearing the voice of the people. However, this formulation did not represent a fundamental departure from the pre-reform constraints that the people's participation was to be channelled into an 'orderly' form by Party and state organisations. One of the ways in which principles of democracy were to be institutionalised was through strengthening the system of people's congresses and instituting local elections. ${ }^{25}$ Mass organisations such as the trade unions (as part of the transmission belt) were also to play a key role in transmitting popular views to the central authorities and participating in policy formation and legislative drafting. Trade unions then had the task of propagating Party policies and decisions back to the workers, and ensuring compliance with centrally issued policy and law. These basic structures allow for orderly (and so, managed and constrained) public participation in the administration of state and social affairs in accordance with the law. But at the same time, they continue to require submission of the minority to majority, the unconditional obligation of lower agencies to carry out decisions of higher-level organs and the personal responsibility of all Party members to implement Party decisions. ${ }^{26}$ Deng Xiaoping also articulated the principles that ' $[\mathrm{U}]$ nder this system, personal interests must be subordinated to collective ones, the

\footnotetext{
22 lbid., p. 15.

${ }^{23}$ Howland, "Popular Sovereignty and Democratic Centralism in the People's Republic of China ".7.

${ }^{24}$ Xiaoping Deng, "Emancipate the Mind, Seek Truth from Facts and Unite as One in Looking to the Future," in Selected Works of Deng Xiaoping (1975-1982), ed. Lenin Bureau for the Compilation and Translation of Works of Marx, Engels and Stalin under the Central Committee of the Communist Party of China (Beijing: Foreign Languages Press, 1978).

${ }^{25}$ Howland, "Popular Sovereignty and Democratic Centralism in the People's Republic of China ".8-9.

${ }^{26}$ Angle, "Decent Democratic Centralism."27.
} 
interests of the part to those of the whole, and immediate to long-term interests'. ${ }^{27}$

The mass line as a method of leadership that places particular emphasis upon creating and maintaining a close relationship between Party and government officials and the masses has again become prominent under Xi Jinping since 2012. It involves mobilising and shaping popular opinion and being seen to respond to it. The mass line has been redeployed as a way of both being seen to engage with the people and as a way of disciplining Party and state officials. A recent example is in June 2013, when Xi Jinping launched a mass line campaign stating that official work should focus on the needs and interests of the ordinary people, and cracking down on what he labelled four types of official decadence: formalism, bureaucratism, hedonism and extravagance. ${ }^{28}$

A vision of democratic centralism is also reflected in the Fourth Plenum Decision, which represents the latest authoritative statement about the Party's view of the nature, objectives and priorities of rule of law in China. It asserts the 'organic unity' of the interests of the Party and the people, with rule of law as a means to achieve both Party leadership and people's democracy. ${ }^{29}$ Rule of law, according to the Fourth Plenum Decision, not only affirms Party leadership over socialist rule of law, but also equates socialist rule of law with Party leadership: 'Party leadership and socialist rule of law are identical, socialist rule of law must persist in Party leadership, Party leadership must rely on socialist rule of law.'-30 Law is also seen as a way to institutionalise and legalise democracy. The Fourth Plenum Decision asserts:

We must persist in the fact that rule of law construction is for the people, relies on the people, benefits the people and protects the people, guarantees the people's basic rights and interests into a starting point and stopover point, guarantees that the people enjoy broad rights and freedoms according to the law, bearing the duties they should, safeguards social fairness and justice, and stimulates common prosperity.

The Fourth Plenum Decision asserts that the rule of law is a way to guarantee the 'people's democracy'. Rule of law and the Constitution do not, Ding argues, stand outside of and above the Party or the people, as a liberal interpretation of rule of law would insist. Instead, he argues that law should be understood as reflecting the people's will; where the Party leads and represents the people in authoring the law and where both the Party and the people are also the guarantors of enforcement and respect for law. Rather than being governed by law, according to Ding, rule of law should be seen as a form of self-

\footnotetext{
${ }^{27}$ Deng, "Emancipate the Mind, Seek Truth from Facts and Unite as One in Looking to the Future."

${ }^{28}$ China Daily, "About Cpc's Mass Line Campaign," China Daily (19 July 2013). http://www.chinadaily.com.cn/china/2013massline/2013-07/19/content_16800244.htm

${ }^{29}$ Xiaodong Ding, "Law According to the Chinese Communist Party: Constitutionalism and Socialist Rule of Law," Modern China 43, no. 3 (2017).

${ }^{30}$ Some Major Questions on Comprehensively Promoting Governing the Country According to Law (Fourth Plenum Decision).
} 
governance. $^{31}$ Viewed in this way, ongoing legal popularisation campaigns ${ }^{32}$ (or legal propaganda) that seek to increase legal consciousness and law-abiding behaviour do not aim to strengthen individual rights consciousness, which can be used against the partystate. Instead, they aim to increase responsibility to the law, encourage popular engagement with Party programs and strengthen Party legitimacy as both leading and reflecting the popular will through law. ${ }^{33}$ Law is thus one of the institutional mechanisms that gives specific form to the relationship between the Party and the people, imagined under a model of democratic centralism.

\subsection{Institutional Form}

The principle of democratic centralism as both ideology and institutional form is also articulated in both the Party Charter and state Constitution. The state Constitution at article 3 provides that: 'The state organs of the People's Republic of China apply the principle of democratic centralism.' This organisational principle designates the relationship between central and local agencies, people's congresses and the government, courts and the procuratorate, as well as the organisation within government agencies (under the leadership responsibility system) . 34

Analysed from an institutional perspective, commentators on the meaning of democratic centralism in the Constitution follow the structure of article 3 to focus on the location of both democracy and centralism within the organisational structure of the state. Article 3.2 describes the National People's Congress and the local people's congresses at various levels as democratically constituted through democratic elections. They are responsible to the people and subject to their supervision. Articles 3.3 and 3.4 describe the centralist organisation under which all administrative, judicial and procuratorial organs of state are created by the people's congresses, to which they are responsible and by which they are supervised. It goes on to provide: '[T] he divisions of functions and powers between the central and local state organs is guided by the principle of giving full scope to the initiative and enthusiasm of the local authorities under the unified leadership of the central authorities.'-35 The constitutional principle of dual supervision organised both horizontally (under the people's congress at the same administrative level) and vertically (by the organ hierarchically superior) gives organisational form to the relationship between democracy

\footnotetext{
${ }^{31}$ Ding, "Law According to the Chinese Communist Party: Constitutionalism and Socialist Rule of Law.", pp. 324, 331-2.

32 Discussed most recently in Susan Whiting, "Authoritarian "Rule of Law" and Regime Legitimacy," Comparative Political Studies (2017).

33 Ding, "Law According to the Chinese Communist Party: Constitutionalism and Socialist Rule of Law."331-334.

34 Ling 马岭 Ma, "The Principle of Democratic Centralism in China's Current Constitution (Woguo Xianxing 'Xianfa" Zhong De Minzhu Jizhong Yuanze 我国现行《宪法》中的民主集中制原则)," Journal of Yunnan University, Law edition (Yunnan Daxue Xuebao Faxue Ban 云南大学学报法学版) 26, no. 4 (2013).

${ }^{35}$ Art. 3(4), Constitution of the PRC 1982.
} 
and centralism. ${ }^{36}$

Even though the constitution suggests that horizontal supervision, exercised by people's congresses at each level, is the primary supervisory mechanism, constitutional scholar Jiang Shigong asserts that the core supervisory mechanism lies in the vertical relationship of subordination of local to central authority in the Party committees organised at each level. That is centralised controls, represented by subordination to higher level agencies, are more important than democratic controls represented by accountability to people's congresses.. He draws on Mao Zedong's 1956 speech On the Ten Major Relationships, in which Mao prescribed consulting local authorities before policies are determined and relying on the initiative of local authorities, but ultimately subjecting localities to strict central control. Jiang argues that these prescriptions constitute a political interpretation of the constitution that is implemented in practice. This political principle forms part of what he describes as the 'unwritten constitution'. ${ }^{37}$. Democratic centralism is thus not only articulated in the constitutional text, but also establishes extra-constitutional political practice that displaces the people's congresses (representing democratic principles) and reasserts the supremacy of the Party's vertical (and so centralist) control mechanisms.

A characteristic of Party organisation is the strength of vertical systems of accountability and control. Party discipline requires obedience to central instructions and policies, and institutes mechanisms of vertical control. For example, the Party personnel system is highly centralised. In allocating positions to Party members, it pays close attention to rank, which determines not only salary and benefits but also scope of decision-making power and position in the hierarchy of power. ${ }^{38}$ Since the beginning of the Xi Jinping regime in 2012 , recentralisation of power has seen the balance shift away from decentralisation and local autonomy to an increasingly centralised control of policy and administration. ${ }^{39}$.

Many Chinese commenters assert that democratic centralism operates at the level of an organisational principle that is reflected in institutional arrangements of Party and state, and does not extend to influencing functional or operational principles of governance. ${ }^{40}$ But, the structural aspects of democratic centralism cannot help but have an impact on modes of governance; particularly on the ways both policy and law are drafted and enforced. As Flora Sapio has argued, constitutional basic principles 'produce their effects

\footnotetext{
${ }^{36}$ The constitutional provision of state organisation that combines vertical and horizontal modes of supervision, with horizontal control under the people's congress at the same level having priority, under the rubric: 条块结合 一块为主. Party control systems on the other hand operate vertically.

${ }^{37}$ Shigong Jiang, "Written and Unwritten Constitutions: A New Approach to the Study of Constitutional Government in China," Modern China 36 (2010).

38 Ling Li, "'Rule of Law" in a Party-State: A Conceptual Interpretive Framework of the Constitutional Reality of China," Asian Journal of Law and Society 2, no. 1 (2015).

${ }^{39}$ Sangkuk Lee, "An Institutional Analysis of Xi Jinping's Centralization of Power," Journal of Contemporary China 26, no. 105 (2017).

40 Journal of Yunnan University, (Law edition) 26, 4 (2013). 2-14.
} 
throughout the entire political and legal system'. ${ }^{41}$ The question of what (if any) impact democratic centralism has on the mode of governance is explored in the following section.

\section{IMPLICATIONS AND APPLICATIONS FOR GOVERNANCE CAMPAIGN- STYLE ENFORCEMENT}

As the discussion so far has shown, since establishment of the PRC, and even before that, the ways in which the principles of democratic centralism have been given shape have been constantly in motion, both in China and other Leninist regimes. The acceptance of, and shifts in, the meaning of democratic centralism in the former Soviet Union, for example, is discussed in Partlett's chapter in this volume. There has been movement over time between decentralisation and centralisation, between emphasising democracy and insisting on centralisation, as well as changes in the ways in which principles of democracy have been given form. The preceding discussion illustrates the important ideological and institutional effects of democratic centralism. From here, I ask how, if at all, the institutional and organisational principles of democratic centralism shape enforcement practice. At one extreme, it could well be argued that democratic centralism permeates the whole edifice of rule of law and the functioning of the legal system as a whole. At the other, it might be argued that democratic centralism provides little assistance in understanding the ways in which rule of law is conceived and implemented in day-to-day governance, which might ultimately be explained in terms of command and control modes of administration. This next section seeks to make apparent the ways in which modes of law making and enforcement swing between favouring centralisation and decentralisation. But more than that, it explores the organisational and political aspects of campaigns that are explicable in terms of democratic centralism, and which go beyond ordinary forms of bureaucratic governance. The example of campaign-style enforcement illustrates the preference for centralised approaches to be taken during periods of perceived crisis, particularly where widespread failure of decentralised law enforcement has led to deep popular dissatisfaction, reflected in extensive public and socially disruptive protest.

\subsection{The Problem: Wages Arrears}

Many workers in China have difficulty getting paid-wages are paid late, with unauthorised or illegal deductions, and in some cases they don't get paid at all. In 2016, the Ministry of Human Resources and Social Security (MOHRSS) reported that this problem affected 2,369,000 migrant workers. ${ }^{42}$. While wages insecurity is widespread, the impact falls mainly on workers in insecure and informal work environments, such as construction,

\footnotetext{
${ }^{41}$ Flora Sapio, "Seeking Truth from Facts in Party Discipline Legislation " in 10th Annual conference of the European China Law Studies Association (Cologne25-27 September 2015).11.

42 Ministry of Human Resources and Social Security, "Second Plenary Meeting of the Inter-Ministerial Joint Meeting on Efforts to Resolve the Problem of Wage Arrears (解决企业拖欠工资问题部际联席会议第二次全体 会议召开)," (15 March 2017).
} 
infrastructure projects, labour intensive production and service sectors like hospitality and retail. ${ }^{43}$ Migrant workers suffer disproportionately. ${ }^{44}$ This problem has consistently attracted the attention and concern of central authorities, at both Party and government level. ${ }^{45}$ While this conduct is illegal and seriously harms the rights of large numbers of workers, one of the main motivations for paying attention to this problem has been that wage theft, including failure to pay wages on time, in full or at all, causes a great deal of socially disruptive protest. Wage-related disputes, in the form of strikes and protests, have risen continuously since the introduction of labour market reforms. ${ }^{46}$ Extra-legal mobilisation, particularly where it disrupts social order, is bound to attract the attention of local Party and state authorities. Their satisfactory performance appraisal depends upon preventing or responding quickly to dissipate disruptive conduct, and so they remain particularly sensitive to signs of social instability. ${ }^{47}$

The increase in socially disruptive protests not only reflects the extent of labour disputes, and disputes about wages in particular, but also reflects the inability of established modes of dispute resolution to address these systematic problems. A number of factors combine to cause this. The first is that no good mechanisms exist for the negotiation of disputes about economic interests (in contrast to legally defined rights), such as wage increases and working conditions. Existing models of collective negotiation are premised on strong trade union intervention to negotiate on behalf of workers. However, beholden to both management at the local level and required to implement Party policy at other levels, the unions have been unequal to this task. ${ }^{48}$ Unions are also required to dissipate and resolve disputes, so they are unable to provide unequivocal representation and support for

\footnotetext{
${ }^{43}$ General Office of the State Council, Opinion on Comprehensively Managing the Problem of Non-Payment of Migrant Workers' Wages (国务院办公厅关于全面治理拖欠农民工工资问题的意见)，2016， http://www.gov.cn/zhengce/content/2016-01/19/content_5034320.htm.

${ }^{44}$ China Labour Bulletin, "Wages and Employment," China Labour Bulletin (2016); Sean Cooney, "Making Chinese Labor Law Work: The Prospects for Regulatory Innovation in the People's Republic of China," Fordham International Law Journal 30, no. 4 (2007); Gerard Greenfield and Tim Pringle, "The Challenge of Wage Arrears in China," in Paying Attention to Wages, ed. Manuel Simón Velasco (Geneva: International Labour Organisation, 2002).

${ }^{45}$ See for example "The Challenge of Wage Arrears in China."More recently (国务院办公厅) General Office of the State Council, "Opinion on Comprehensviely Managing the Problem of Non-Payment of Migrant Workers' Wages (关于全面治理拖欠农民工工资问题的意见)," (17 January 2016); Biddulph, Cooney, and Zhu, "Rule of Law with Chinese Characteristics: The Role of Campaigns in Law-Making."

${ }^{46}$ China Labour Bulletin, "Wages and Employment."; "Strike Map," China Labour Bulletin; "Wages in China " (19 February 2008). http://maps.clb.org.hk/strikes/en.

${ }^{47}$ Biddulph, The Stability Imperative: Human Rights and Law in China. 21.

${ }^{48}$ Feng Chen, "Between the State and Labour: The Conflict of Chinese Trade Unions' Double Identity in Market Reform," The China Quarterly (2003); "Individual Rights and Collective Rights: Labor's Predicament in China," Communist and Post Communist Studies 40, no. 1 (2007); Feng Chen, "Trade Unions and the Quadripartite Interactions in Strike Settlement in China " The China Quarterly 102 (2010); Eli Friedman and Ching Kwan Lee, "Remaking the World of Chinese Labour: A 30 Year Retrospective," British Journal of Industrial Relations 48, no. 3 (2010). Sarah Biddulph, "Responding to Industrial Unrest in China: Prospects for Strengthening the Role of Collective Bargaining," Sydney University Law Review 34, no. 1 (2012).
} 
workers in rights-based disputes either. ${ }^{49}$ The second is that it remains difficult for an individual to obtain a quick and satisfactory resolution to a dispute about legally defined labour rights through the legally prescribed channels of mediation, labour arbitration and litigation, despite substantial changes to facilitate workers in the disputing process under the 2007 Labour Disputes Mediation and Arbitration Law. ${ }^{50}$ The legal form of dispute resolution tends to individualise disputes and the capacity of workers to obtain legal assistance from union representatives, lawyers or worker activists is limited in a number of ways. ${ }^{-51}$ Third, labour laws also give primary responsibility for enforcement, including enforcement of pay entitlements, to MOHRSS. ${ }^{52}$ However, the labour inspectorate is notoriously unwilling to enforce the law stringently or impose the maximum sanction permitted by law because it is understaffed, risk averse, subject to undue influence from local governments with competing priorities and, in some cases, corrupt. ${ }^{53}$ Finally, where labour disputes become disruptive, local officials often circumvent the law in an effort to dissipate them. ${ }^{-54}$ This creates a perverse incentive to behave even more disruptively in the hope that an extra-legal resolution will be forthcoming. ${ }^{55}$.

In the construction industry, which predominately employs migrant workers, these problems are exacerbated by a widespread failure to enter into written labour contracts, as required by law. The construction industry is also characterised by many levels of subcontracting, from the head contractor down to the subcontractor who provides workers for the site. As a result, many workers are unable to identify their employer. ${ }^{56}$.

\footnotetext{
${ }^{49}$ Chen, "Individual Rights and Collective Rights: Labor's Predicament in China."; Anita Chan, "Strikes in China's Export Industries in Comparative Perspective," The China Journal 65 (2011).

50 Sean Cooney, Sarah Biddulph, and Ying Zhu, Law and Fair Work in China (London: Routledge, 2013). Mediation and Arbitration Management Division(调解仲裁管理司), "The Responsible Person in the Ministry of Human Resources and Social Security Mediation and Arbitration Management Division Responds to a Journalist's Questions About the 'Opinion on Further Strengthening the Multidisciplinary Mechanism of Mediation and Arbitration of Labor and Personnel Disputes (人社部调解仲裁管理司负责人就《关于进一步加强劳动人事争议 调解仲裁完善多元处理机制的意见》答记者问)," (1 April 2017).

${ }^{51}$ Aaron Halegua, "Who Will Represent China's Workers? Lawyers, Legal Aid and the Enforcement of Labor Rights," New York University School of Law U.S., Asia Law Institute (October 2016). "Getting Paid: Processing the Labor Disputes of China's Migrant Workers," Berkeley Journal of International Law 26, no. 1 (2008). Cooney, Biddulph, and Zhu, Law and Fair Work in China.pp. 74-5.

52 Halegua, "Who Will Represent China's Workers? Lawyers, Legal Aid and the Enforcement of Labor Rights."; Cooney, Biddulph, and Zhu, Law and Fair Work in China.pp./ 64-69.

${ }^{53}$ Virginia Ho, "From Contracts to Compliance? An Early Look at Implementation under China's New Labor Legislation " Columbia Journal of Asian Law 23, no. 1 (2009). Anita Chan, China's Workers under Assault (Armonk: M.E. Sharpe, 2001). Ching Kwan Lee, Against the Law: Labor Protests in China's Rustbelt and Sunbelt (Berkeley: University of California Press, 2007). Cooney, Biddulph, and Zhu, Law and Fair Work in China.pp. 73-74.

${ }^{54}$ Ching Kwan Lee and Yonghong Zhang, "The Power of Instability: Unraveling the Microfoundations of Bargained Authoritarianism in China," American Journal of Sociology 118, no. 6 (2013). Yang Su and Xin He, "Street as Courtroom: State Accommodation of Labour Protest in South China," Law \& Society Review 44, no. 1 (2010). ${ }^{55}$ Biddulph, The Stability Imperative: Human Rights and Law in China.

${ }^{56}$ Ngai Pun and Huilin Lu, "A Culture of Violence: The Labor Subcontracting System and Collective Action by Construction Workers in Post-Socialist China," The China Journal 64 (2010). Wei Deng, "Resolving Unpaid Wages by Spring Festival: Mission Impossible? ," People's Daily Online (15 January 2004); Wanning Sun, "Desperately Seeking My Wages: Justice, Media Logic, and the Politics of Voice in Urban China," Media, Culture and Society 37, no. 4 (2012).
} 
Even if they can, the subcontracting arrangement may be illegal or the subcontractor, if contracting as an individual, may not have legal status to enter into an employment relationship with the workers, thus rendering the protective provisions of labour law inapplicable and the worker the status of an independent contractor. Enforcing wage payment obligations in these circumstances is an almost insurmountable legal and practical hurdle.

Where social order problems are acute and ongoing, and where local intervention has been ineffectual, central authorities intervene. ${ }^{57}$ A repeating pattern has emerged in relation to wages arrears. During times when sensitivity about social order is high, when it is politically convenient and where the disruptive consequences of widespread problems of wage arrears reach the attention of central authorities, a centrally coordinated series of responses are undertaken, as they claim, to deal with the problem once and for all. In theory, there is a natural division between dispute resolution mechanisms and campaigns. The former is intended to resolve disputes after they arise and the latter is directed towards addressing underlying systemic problems. In practice, the division is not as clear, as campaigns are also directed at resolving grievances that exist and have not yet been resolved, rectifying practical and bureaucratic impediments to enforcing labour law, and addressing the systematic problems that underlie wages disputes.

This chapter reviews three illustrations of wage-related campaigns. The first is the 20042007 Wages Campaign. The second is the annual 'clean-up' to address problems of unpaid wages before Chinese Lunar New Year. The third is the concerted action launched by the State Council in January 2016.

\subsection{What Is a Campaign? Past and Present}

Campaigns were widely used as a mode of coordinated Party action in the pre-reform period (between 1949 and 1978), when they were frequently characterised by intensive mass mobilisation with revolutionary objectives of overcoming 'barriers to the progress of socialism'. 58 They are commonly viewed as Maoist. However, their form, as will become clear in the discussion below, draws on the organisational and institutional structure of democratic centralism and the mass line. They were a powerful ideological tool, intended to transform their target to assert the 'correct line', to change popular attitudes and social institutions, and to purge those officials seen to transgress. ${ }^{-59}$ Campaigns in the pre-reform

\footnotetext{
${ }^{57}$ The deleterious impact on social stability was a core motivating factor for the 2004-2007 Wages Campaign, discussed below and more recently in the General Office of the State Council, Opinion on Comprehensively Managing the Problem of Non-payment of Migrant Workers' Wages (国务院办公厅关于全面治理拖欠农民工工 资问题的意见) issued on 20 January 2016; see also Benjamin van Rooij, "Regulation by Escalation: Unrest, Lawmaking and Law Enforcement in China," in The Politics of Law and Stability in China, ed. Susan Trevaskes, et al. (Cheltenham: Edward Elgar Publishing).

${ }^{58}$ Gordon Bennett, Yundong: Mass Campaigns in Chinese Communist Leadership (Berkeley: University of California Press, 1976).

59 Ibid. Benjamin van Rooij, "The Politics of Law in China: Enforcement Campaigns in the Post-Mao Prc," http://ssrn.com/abstract=136181 (2009); Julia Strauss, "Morality, Coercion and State Building by Campaign in the
} 
period were not entirely antithetical to, or disruptive of, the institutionalisation of power; however, they commonly operated with disregard for law or lawfulness. ${ }^{-60}$

Early in the reform era, the campaign form was redeployed, most famously in the threeyear Strike Hard (Yanda) campaign waged between 1983 and 1986. In its initial phase, the Yanda campaign was lawless. However, Peng Zhen, a top Party leader in the law and order system at the time, quickly asserted that the campaign should be conducted 'in accordance with law'. ${ }^{61}$ Despite this demand, there remains a degree of tension between responding to the call to 'strike hard and fast' and the demands of the legal principles of substantive and procedural justice. In an era that purported to move away from Maoism and its revolutionary ideology and practice towards a more institutionalised and bureaucratised model of legalised justice, the question of whether the continued use of campaigns should be seen as a remnant 'of the politicised legal past'-62 remained. Michael Dutton has argued that it should not, characterising the campaign as now being a technocratic tool of punishment, rather than an ideological tool of transformation. ${ }^{63}$ Despite transformation from ideological to technocratic tools, campaigns in the reform era continue to draw strongly on their pre-reform counterparts in terms of structure and method.

While campaigns differ in terms of degree of politicisation, geographical scope, extent and time, all campaigns in the reform era share the characteristics of 'coordinated operation' (tongyi xingdong), with intensified and focused enforcement activities by Party and state agencies at multiple levels, using the formula of 'striking hard and fast' against the targeted conduct or problems (congzhong congkuai daji). Coordination is achieved through the establishment of a central leadership group that determines and allocates tasks, and timing and performance targets, with corresponding leadership groups formed at local levels. Leadership groups organise and direct the campaign, and receive periodic reports on the performance of participating agencies against set targets. They combine propaganda, education and mobilisation of the public in support of campaign objectives. Nationwide campaigns are often divided into three one-year battles (zhanyi), each with their own targets and reporting requirements. Campaigns may be waged within the Party hierarchy or the state hierarchy. Or, more commonly for national level campaigns, they may involve coordinated Party, state and societal action.

\footnotetext{
Early Prc; Regime Consolidation and after, 1949-1956," The China Quarterly 188 (2006); Michael Dutton, "Dreaming of Better Times: 'Repetition with a Difference' and Community Policing in China," positions east asia cultures critique 3, no. 2 (1995).

${ }^{60}$ Bennett, Yundong: Mass Campaigns in Chinese Communist Leadership.p. 18. Strauss, "Morality, Coercion and State Building by Campaign in the Early Prc; Regime Consolidation and after, 1949-1956.".

${ }^{61}$ Zhen Peng, "The Hard Strike against Crime Must Abide by the Law, Pay Attention to Policy and Strengthen Comprehensive Management," ed. National Conference of Public Security Office and Division Heads (15-22 November 1983); Sarah Biddulph, Legal Reform and Administrative Detention Powers in China (Cambridge: Cambridge University Press, 2007). This rhetorical commitment has been reasserted periodically. See Xianguo Xiong, "Yifa "Yanda" ("Strike Hard" According to the Law)," (Renmin Fayuan Bao (People's Court Daily), 2001). 62 van Rooij, "The Politics of Law in China: Enforcement Campaigns in the Post-Mao Prc."5.

63 Dutton, "Dreaming of Better Times: 'Repetition with a Difference' and Community Policing in China."'Dreaming of Better Times'.
} 
While there is no straightforward typology of campaigns in the reform era, some examples illustrate their breadth of application. Probably the best-known use of campaigns is against criminal behaviour. ${ }^{64}$ Campaigns have also been waged against lesser forms of anti-social conduct. In addition to these nationwide campaigns, the justice organs of the state regularly conduct coordinated actions (jizhong tongyi xingdong), specialist struggles (zhuanxiang douzheng) and specialist rectifications (zhuanxiang zhili) dealing with more narrowly focused targets, often in a more constrained geographical area. 65

Another well-known set of examples relate to problems of internal Party and state governance. The ongoing anti-corruption campaign is one example. ${ }^{-66}$ Campaign-style enforcement also draws on the campaign model in addressing serious problems in areas of economic and environmental regulation;-regulatory failure campaigns. ${ }^{-67}$. These types of campaigns include those addressing problems such as environmental pollution, loss of rural land, food safety and pirating of famous brand name consumer products. ${ }^{-68}$ Wages campaigns fall within this category, as they are primarily responsive to social disruption arising out of regulatory failure.

\subsection{The 2004-2007 Wages Campaign}

From the late 1980s, the incidents of social protest and self-harm, and the instability related to labour abuses (such as widespread failure to pay wages) escalated. The construction industry was one of the areas of worst abuse. ${ }^{-69}$ In the early 2000 s, a number of highly publicised episodes were reported sympathetically in the media, including the case of a migrant worker, Xiong Deming, seeking Premier Wen Jiabao's assistance in recovering unpaid wages, and another migrant worker threatening suicide over wage arrears. ${ }^{70}$ The increasing activism and publicity surrounding efforts by migrant workers to get paid, coupled with spreading disruptive protest, was quickly identified as a threat to social order and attracted the attention of central Party and state leaders. ${ }^{-71}$ The 2004 2007 Wages Campaign shares characteristics with other campaigns in that it was initiated

\footnotetext{
${ }^{64}$ Susan Trevaskes, "Severe and Swift Justice in China," British Journal of Criminology 47 (2007). "Yanda 2001: Form and Strategy in a Chinese Anti-Crime Campaign," Australian and New Zealand Journal of Criminology 36, no. 3 (2003); Murray Scot Tanner, "State Coercion and the Balance of Awe: The 1983-1986 "Stern Blows" Anti Crime Campaign," The China Journal 44 (2000); Biddulph, Legal Reform and Administrative Detention Powers in China.

65 Legal Reform and Administrative Detention Powers in China.

${ }^{66} \mathrm{Xi}$ Jinping launched this campaign in 2012 and it remains ongoing at the time of writing. See discussion in Willy Wo-Lap Lam, "China's Anti-Graft Campaign in Review," China Brief 15, no. 23 (7 December 2015).

${ }^{67}$ Biddulph, Cooney, and Zhu, "Rule of Law with Chinese Characteristics: The Role of Campaigns in LawMaking."Law and Fair Work in China.

${ }^{68}$ See for example van Rooij, "The Politics of Law in China: Enforcement Campaigns in the Post-Mao Prc."

${ }^{69}$ Discussed in Biddulph, Cooney, and Zhu, "Rule of Law with Chinese Characteristics: The Role of Campaigns in Law-Making."375, 379.

70 Sun, "Desperately Seeking My Wages: Justice, Media Logic, and the Politics of Voice in Urban China."864-865.

71 Jae Ho Chung, Hongyi Lai, and Ming Xia, "Mounting Challenges to Governance in China: Surveying Collective Protestors, Religions Sects and Criminal Organizations," The China Journal 56 (2006).; Wei Li, "How to Prevent and Control the Masses Engaging in Collective Petitioning (Ruhe Yufang He Kongzhi Qunzong Jiti Shangfang)," The Secretary's Friend (Mishu zhi You), no. 3 (1999).
} 
and led from the centre; it involved coordinated implementation with target setting and periodic reporting back; breaches were punished severely, quickly and publicly; and it was accompanied by extensive use of the media to educate the people and shame transgressors.

\subsubsection{Central Leadership}

The early 2000s were also a politically opportune time, as the new leadership of Hu Jintao and Wen Jiabao had signalled the importance of dealing with wages arrears as part of their policy to rebalance economic development with social development and equity, under the rubric of the Harmonious Society Policy. ${ }^{72}$ The National People's Congress (NPC) Standing Committee had laid the groundwork through its investigation into the implementation of the Construction Law, carried out by the NPC Standing Committee in 2003. That report identified chronic and severe problems of failure to pay wages, which not only disrupted market order but also directly impacted on social stability. Li Tieying, the Standing Committee Vice-Chairman, demanded an urgent 'three year clean-up' (sannian qingqian) campaign to address compliance failures. ${ }^{73}$

\subsubsection{Coordinated Implementation of Law Enforcement and Law Making}

The campaign was directed by the Inter-Ministerial Liaison Committee on Resolving the Problem of Non-Payment of Construction Funds (the Inter-Ministerial Committee), under the leadership of Vice-Premier Zeng Peiyan. The Inter-Ministerial Committee issued documents that allocated targets for all participating agencies. It demanded that agencies 'crack down hard' (yanli daji) against all types of unlawful and criminal acts, and 'strengthen inspection and enforcement and assist migrant workers in recovering wages'; and that penalties be strengthened. The campaign was thus not merely about improving enforcement of legal regulations, but also achieving a substantive pro-worker objective. Documents setting out the timetable and a detailed division of responsibility between Party, state, judiciary and other social organisations responsible for implementing the campaign used military-style rhetoric of 'deploying the forces' (bushu). Corresponding committees at local levels were also established to oversee compliance with

\footnotetext{
72 The Harmonious Society policy was formally adopted at the close of the Sixth Plenary session of the $16^{\text {th }}$ CPC Central Committee meeting on 11 October 2006, in the Resolution on Major Issues Regarding the Building of a Harmonious Socialist Society, announced at www.china.org.cn/english/report/189591.htm. It was first raised by Hu Jintao in his inaugural report to the $16^{\text {th }}$ CPC Congress in 2002; 'Strategic Intent to Build a Harmonious Society', People's Daily, 24 February 2005, available at http://politics.people.com.cn/GB/8198/70195/70203/4757848.html.

${ }_{73}$ NPC Standing Committee, "Npc Standing Committee Law Enforcement Investigation Group 'Report on the Implementation of the Prc Construction Law' (Quanguo Renda Changweihui Zhifa Jiancha Zu Guanyu Jiancha "'Zhonghua Renmin Gongheguo Jianzhu Fa' Shishi Qingkuang De Baogao') " China Construction Information Web (6 November 2003).; People's Daily Online, "The State Council Deploys to Rectify the Delayed Payment of Construction Funds in the Construction Sector: Zeng Peiyan Emphasises That before Spring Festival Each Region Must Pay Close Attention to Payment of Migrant Workers Unpaid Wages from the Previous Year," (3 January 2004); Xinhua News Agency, "Resolving Delayed Payment of Wages in the Construction Sector: 5 Trump Cards in Blocking Off the Deadbeats'usual Escape Routes," (16 December 2003).
} 
implementation and reporting requirements. ${ }^{-74}$

A distinguishing feature of campaigns such as the 2004-2007 Wages Campaign is that they recentralise control, emphasising vertical control mechanisms (centralism) at the expense of local autonomy and as a way of overcoming inefficiencies in decentralised models of enforcement. It purposely breaks down institutional silos and blurs boundaries between state and judicial agencies and their spheres of authority; state and Party agencies and their spheres of operation; and state, Party and mass organisations, such as the All-China Federation of Trade Unions (ACFTU). For the duration of the campaign, priority must be given to the tasks of the campaign over other work. So, for example, the courts were required to give priority to cases involving wage claims, waive fees and find in favour of migrant workers where possible, as well as do their utmost to ensure enforcement of court judgements in this category of case. These instructions were subsequently set out in binding form in an urgent notice to all courts issued by the Supreme People's Court. ${ }^{75}$ In addition to coordinating and strengthening enforcement, agencies were instructed to draft new regulations to rectify regulatory gaps and inadequacies, so the campaign also had a direct impact on law reform. ${ }^{76}$

At the local level, provincial governments were responsible for evaluating performance of county governments and agencies against centrally set targets and the corresponding targets allocated in their own local plans. By setting enforcement targets, local agencies were given standards against which their performance was to be judged. ${ }^{77}$ Where provinces failed to meet performance targets they were publicly named and shamed. These documents also made clear that leaders and other designated responsible people would be liable for punishment (both in terms of eligibility for performance bonuses and career promotion) if they failed to meet their performance targets or were not diligent in implementing the campaign. To ensure that local agencies did not merely report that the targets had been met without actually achieving them, both periodic and random inspections were carried out by the campaign leadership group, higher level agencies and other agencies such as the trade unions, people's congresses and the people's consultative committees. ${ }^{78}$ Local governments thus ran the risk of being discovered if they completely fabricated their reports.

Despite the fact that local agencies are adept at giving the appearance of compliance while

\footnotetext{
${ }^{74}$ See generally Biddulph, Cooney, and Zhu, "Rule of Law with Chinese Characteristics: The Role of Campaigns in Law-Making."Law and Fair Work in China.

${ }^{75}$ SPC Urgent Notice on Concerted Action to Put in Order Cases on the Delayed Payment of Construction Funds and Wages of Migrant Workers, December 2004.

${ }^{76}$ Biddulph, Cooney, and Zhu, "Rule of Law with Chinese Characteristics: The Role of Campaigns in LawMaking."Law and Fair Work in China.

${ }^{77}$ On performance controls generally, see Maria Edin, "State Capacity and Local Agent Control in China: Ccp Cadre Management from a Township Perspective," The China Quarterly 173 (2003).

${ }^{78}$ See for example, Ministry of Construction, Basic Situation on the Nationwide Resolution of the Problem of Delayed Payment in the Construction Sector of Construction Funds and Migrant Worker Wages, September 2004, at section 2.1, available at www. hnup.com/xhpaper/article. asp?id=168\&classid=44.
} 
not actually changing their ordinary practices, the imposition of targets meant that the 2004-2007 Wages Campaign changed, albeit temporarily, the balance of autonomy and control between central and local authorities. As with other campaigns, the 2004-2007 Wages Campaign provided a systematic form of intervention by which central authorities could weaken foot dragging and obstruction inspired by local protectionism. A key aspect of such campaigns is that they are sporadic and so enable the centre to insist on its priorities for a defined period, while also allowing space for different and sometimes conflicting local objectives to be pursued outside of the period of the campaign. ${ }^{79}$

\subsubsection{Propaganda and Education}

As with all mass line activities, propaganda and education comprise key elements of the campaign. During the 2004-2007 Wages Campaign, the media was called upon to report egregious cases, publicise black lists of recalcitrant enterprises, educate people about the campaign and its objectives, and encourage active engagement with the campaign. Media and publicity also played a central role, beyond education about legal rights and responsibilities, and beyond the existence of the campaign and campaign objectives. This was an opportunity for the media to inculcate people with an appreciation for the care and concern the central authorities have for the welfare of working people. ${ }^{80}$

While the media initially reported sympathetically on worker action stemming from disputes about unpaid wages (including threatened suicide and murder), it later changed its focus to criticising their unlawful behaviour. To discourage this form of protest and to avoid exacerbating the already volatile situation, media reports criticised and mocked this behaviour as ignorant or merely attention seeking. ${ }^{81}$ Media reporting was brought within the ambit of the campaign to fulfil its objectives of educating workers, shaming recalcitrant employers and promoting the achievements of the campaign and, more importantly, the Harmonious Society Policy of the then leadership of Hu Jintao and Wen Jiabao. ${ }^{-82}$ Of course, at the end of the campaign, the official declaration of its success in addressing problems of wages arrears was well publicised. 83

\subsection{Annual Wages Campaigns and the 2015 Harmonious Labour Relations Campaign}

The common form of a regulatory failure campaign is explored in detail in the preceding discussion of the 2004-2007 Wages Campaign. Even though that campaign ended with a

\footnotetext{
${ }^{79}$ Xin He, "Sporadic Campaigns as a Means of Social Control," Columbia Journal of Asian Law 17, no. 1 (2003).

${ }^{80}$ Sun, "Desperately Seeking My Wages: Justice, Media Logic, and the Politics of Voice in Urban China."873; Biddulph, The Stability Imperative: Human Rights and Law in China.240.

${ }^{81}$ Sun, "Desperately Seeking My Wages: Justice, Media Logic, and the Politics of Voice in Urban China."871-3.

82 Biddulph, Cooney, and Zhu, "Rule of Law with Chinese Characteristics: The Role of Campaigns in LawMaking."15-16; Sun, "Desperately Seeking My Wages: Justice, Media Logic, and the Politics of Voice in Urban China."871-2.

83 The then chairman of the NPC Standing Committee, Wu Bangguo, declared the campaign a success on 8 March 2008 at the second plenary meeting of the $11^{\text {th }}$ NPC. China News Web, "Most Provinces in China Have Already Fundamentally Resolved the Historical Problem of Delayed Payment of Wages," (8 March 2008).
} 
declaration that the problem of wage arrears had been resolved, it had not. In a sign that decentralised enforcement and individual dispute resolution mechanisms remain unequal to the task of addressing wages arrears, multi-agency centrally coordinated wages campaigns have been conducted annually since then during the period preceding the Lunar New Year holiday. ${ }^{-84}$ This is a sensitive time, as for many rural migrant workers it is their only opportunity to return home to visit the family members they have left behind. Failing to pay wages at this time of year is thus a much more serious transgression than an an other time.

A recent coordinated effort to address wages arrears dates from 21 March 2015, when the CCP Central Committee and the State Council jointly issued the 'Opinion on Building Harmonious Labour Relations'. ${ }^{-85}$ - This document identifies failure to pay wages to migrant workers as a serious problem undermining social stability (among other problems). Again, we see articulated guiding principles and comprehensive programs to address wages arrears. Propaganda and education accompany these. In August 2015, both central and local levels of government launched a harmonious labour relations awareness month. ${ }^{-86-}$ MOHRSS issued a document setting out the recommended language and terms to be used during this month. -87

On 20 November 2015, MOHRSS convened an inter-ministerial meeting on this issue. It was reported that each region and relevant agency was instructed to 'spring into action' (xingdong qilai) and 'to quickly and comprehensively implement the concerted action' 'to continually strengthen efforts' to deal with the problem of unpaid migrant worker wages. ${ }^{88}$ As with concerted actions of this type, regions and agencies were required to strengthen investigation, enforcement and punishment, and to act in concert to achieve the designated objectives. All local labour bureaux were required to impose severe

\footnotetext{
${ }^{84}$ MOHRSS convened the annual multi-agency inter-ministerial meeting on 20 November 2015. Yujie 张玉洁 Zhang, "Mohrss Convenes the 2016 Annual Work Meeting on Ensuring Payment of Migrant Workers' Wages Prior to Spring Festival 人社部召开 2016 年春节前保障农民工工资支付工作视会," China Organisations and Personnel Daily 中国组织人事报 (23 November 2015).

85 At http://paper.people.com.cn/rmrb/html/2015-04/09/nw.D110000renmrb 20150409 2-01.htm. Similar campaigns to strike hard against malicious refusal to pay wages have also been waged in 2012, 2013 and 2014 . See www.mohrss.gov.cn/SYrlzyhshbzb/ldbk/laodongguanxi/laodongguanxixiediao/201202/t20120202 87337.htm, www.mohrss.gov.cn/SYrlzyhshbzb/zwgk/SYzhengcejiedu/201303/t20130309 87391.htm

${ }^{86}$ For example in: 内蒙古自治区自治区人力资源和社会保障厅 Inner Mongolia Autonomous Region Office of Human Resources and Social Security, "Autonomous Region Undertakes Construction of Harmonious Labour Relations Propaganda Month Activities 自治区开展构建和谐劳动关系宣传月活动," Inner Mongolia Austnomous Region Human Resources and Social Security Web (8 July 2015)., 8 July 2015, available at http://m.jintang114.org/view.php?aid=24241; in Hohot [市人社局开展构建和谐劳动关系宣传月活动] available at www.hhhtld.gov.cn/pub/zhuanyezizhan/laodongguanxi/201509011025.html.

${ }^{87}$ At www.mohrss.gov.cn/.../W020150824502328622853.

88 Zhang, "Mohrss Convenes the 2016 Annual Work Meeting on Ensuring Payment of Migrant Workers' Wages Prior to Spring Festival 人社部召开 2016 年春节前保障农民工工资支付工作视会."There were reportedly 12 other agencies in attendance. Xingwei 孙兴伟 Sun, "Work to Ensure That the Wages Migrant Workers Should Receive Are Paid on Time and in Full（确保农民工按时足额拿到英得工资）," China Labour Protection Daily (中 国芬动保障报) (21 November 2015).
} 
punishments on enterprises that failed to pay migrant worker wages, and to strengthen coordination with public security, procuratorial and adjudication agencies to ensure coordinated and rapid handling of criminal cases of refusal to pay wages. Labour mediation and arbitration agencies were required to establish a 'green channel' to simplify and expedite handling of wages disputes and to liaise with local unions and justice departments on provision of legal aid in wages cases. Repeat offenders and recalcitrant employers were to be entered on the 'black list', which was to be widely publicised in the media, alongside information about strengthened investigations and sanctions. ${ }^{89}$

In January 2016, the General Office of the State Council issued the 'Opinion on Comprehensively Managing the Problem of Non-payment of Migrant Workers' Wages', setting out a five-year agenda to address and redress the non-payment or delayed payment of the wages. ${ }^{90-}$ It directed the focus of this concerted action on the construction sector, labour intensive production and service sectors such as hospitality and retail where problems of wages arrears are concentrated, with work to be completed by 2020. Media reports from this time included praise for police who had helped migrant workers recover unpaid wages. ${ }^{-91}$

On 15 March 2017, MOHRSS reported on the second inter-ministerial meeting of this campaign, receiving reports on work carried out in 2016. It resolved to persist in strengthening coordinated management and striking hard on the serious problem of nonpayment of wages in the construction industry. ${ }^{-92}$ And so the pattern repeats.

\section{CONCLUSION: THE SIGNIFICANCE OF CAMPAIGNS AND CAMPAIGN- STYLE ENFORCEMENT IN THE CHINESE LEGAL SYSTEM}

Both democracy and centralism can be identified in the form and execution of these campaigns. The centralist aspects are illustrated by the centralised, vertical coordination between higher and lower level Party groups, and different agencies of state. The central leadership group allocates tasks and performance quotas across participating Party and state agencies and social organisations, and down the administrative hierarchy to local levels in a manner reminiscent of the central planning system. Significantly, the courts are also included and treated no differently to other administrative agencies, violating widely shared understandings of the separation of powers of liberal democratic societies.

\footnotetext{
${ }^{89}$ Zhang, "Mohrss Convenes the 2016 Annual Work Meeting on Ensuring Payment of Migrant Workers' Wages Prior to Spring Festival 人社部召开 2016 年春节前保障农民工工资支付工作视会."

${ }^{90}$ General Office of the State Council Opinion on Comprehensively Managing the Problem of Non-payment of Migrant Workers' Wages (国务院办公厅关于全面治理拖欠农民工工资问题的意见 20 January 2016

91 Jiaxin 赵家新 Zhao, "Xinghua: Create a Foundation for Stability Let the Masses, Stably Enjoy Peace 兴化: 稳定 根基 让群众 “稳” 享平安," People's Police Daily 人民公安报 (3 February 2016).

92 Second Plenary Meeting of the Inter-ministerial Joint Meeting on Efforts to Resolve the Problem of Wage Arrears[解决企业拖欠工资问题部际联席会议第二次全体会议召开], available at www.mohrss.gov.cn/ldjci/LDJCJgongzuodongtai/201703/t20170317 268101.html.
} 
In the orthodox model of democratic centralism, the Party gathers popular inputs as part of the democratic process, but ultimately makes decisions and policies in ways that do not necessarily respond directly to those inputs. In the case of the wages campaigns, the Party is responsive to the existence of public concerns and the failure to protect the lawful rights of migrant workers. It is also motivated by concerns about social stability and economic development. Once a decision has been made, full compliance is required. Propaganda and education, drawing on mass line techniques, are designed to raise public awareness of both the campaign and their legal rights, to shape and then mobilise public support for the campaign. The public message of these campaigns is that the central authorities are concerned about, and responsive to, the problems of the ordinary people-particularly vulnerable groups such as rural migrant workers. As campaigns all contain some moral message (in this case, sympathy and concern for the welfare of rural migrant workers), they are a vehicle to reiterate the Party's moral leadership, the link between Party and the people, and the link between the Party's moral leadership and law-based governance. ${ }^{93}$

Although there are a number of similarities with enforcement campaigns in Western countries, I would argue that Chinese campaigns are distinct from their Western counterparts. That is because they occur in a political context that permits periods of centralisation, which breaks down the institutional silos and obstacles to legal reform that may arise from a decentralised form of governance, including the separation of governmental functions and the division of function between central and local entities. Campaigns tend to conflate policy and law making, as well as party and state, judicial and administrative power.

What do campaigns tell us about Chinese rule of law with socialist characteristics? Are they an anomaly, or an artefact of transition that will fade as the Chinese legal system matures? Although they do not describe the whole of the legal system, the campaign as a response to periods of perceived crisis or regulatory failure appears to be both widespread and persistent. Campaigns can have a potentially constructive effect on the Chinese legal system. One outcome of the 2004-2007 Wages Campaign was the introduction of new rules by local governments to address non-payment of wages. It also provided the impetus for the drafting and passage of major national labour legislation that was more favourable to workers' interests than the Labour Law. ${ }^{94}$ Campaigns also require a concentrated examination of the deficiencies in the existing legal and regulatory framework, and the formulation of responses to address those problems. However, this chapter has also illustrated that the wages campaigns have been ineffective over decades to address the entrenched problem of wage arrears.

A more pressing problem might be that the continuing reliance on campaign-style

\footnotetext{
${ }^{93}$ The link between governance by virtue and governance by law under the leadership of the Party is restated in the Fourth Plenum Decision.

${ }^{94}$ Biddulph, Cooney, and Zhu, "Rule of Law with Chinese Characteristics: The Role of Campaigns in Law-Making." 389-390.
} 
enforcement perpetuates a political-administrative approach to the development of China's legal system, which emphasises the central and coordinated role of the Party and state agencies. This has a number of consequences. The first is that even though state agencies lack the resources (and, in some cases, the will) to enforce the law at the local level, campaigns divert resources to focus on the problems and targets defined by central Party and state powers. This mode of governance is arguably detrimental to the development of more stable forms of regulation by mid and local level administrative agencies, which lose control over allocation of priorities and resources during campaign periods. Repeated campaigns are not popular. After suffering many years of law and order campaigns, the police renamed Yanda (严打, meaning 'Hard Strike') by using its homophone一 厌打, meaning 'Can't Stand it Strike'.-95

The campaign is also at odds with the establishment of citizen-led, or bottom-up, modes of governance and the development of strong civil society actors to advocate for and assist migrant workers to protect their own rights. While the sporadic nature of campaigns allows local agencies to refocus on their own priorities after the campaign is finished, the campaign form creates instability and uncertainty for both regulatory agencies and those regulated. More generally, it subordinates a legal regulatory approach to the political.

Viewed in light of the principles of democratic centralism, we might see the form and ubiquity of the campaign as not just a question of political interference in the legal domain, but as more of a political and ideological structuring of that domain that has flow-on effects for the functioning of legal and regulatory systems. That said, it is important not to make too much of the example of wages campaigns or the more general example of campaigns. Certainly, they illustrate both the political-administrative orientation and the impact of democratic centralism on the legal system. They do not describe the whole of the legal system or the entirety of the ways in which the legal system functions; either in terms of law making or law enforcement. Nevertheless, campaigns do focus our attention on the impact of democratic centralism on not only the institutional structure of the state and legal system, but also on modes of governance. In particular, campaigns seem to operate at times of perceived social crisis, which, due to the sensitivity of the party-state to social and political instability, is rather more often than we might anticipate.

\section{REFERENCES}

\footnotetext{
95 Shengfu Sun, "Guanyu Jianchi 'Yanda' Fanzhen De Yixie Sikao (Some Reflections on Upholding the Guiding Principle of the 'Hard Strike' )," in Zhongguo Renmin Gong'an Daxue Xiaoqing Shi Zhou Nian Lunwen Xuanji (Selection of Essays for the Tenth Anniversary of the China People's Public Security University) (Beijing: Zhongguo Renmin Gongan Daxue Chubanshe (China People's Public Security University Press), 1994). Sun uses the homophone of Yanda (严打) to express the degree to which police officers are fed up with carrying on campaigns (taoyan yanda [讨厌严厉打击] abbreviated to yanda) [厌打].
} 
Angle, Stephen. "Decent Democratic Centralism." Political theory 33 (2005): 518-46.

Bennett, Gordon. Yundong: Mass Campaigns in Chinese Communist Leadership. Berkeley: University of California Press, 1976.

Biddulph, Sarah. Legal Reform and Administrative Detention Powers in China. Cambridge: Cambridge University Press, 2007.

- - - "Responding to Industrial Unrest in China: Prospects for Strengthening the Role of Collective Bargaining." Sydney University Law Review 34, no. 1 (2012): 35-63.

- - - The Stability Imperative: Human Rights and Law in China. Vancouver: UBC Press, 2015.

Biddulph, Sarah, Sean Cooney, and Ying Zhu. "Rule of Law with Chinese Characteristics: The Role of Campaigns in Law-Making." Law \& Policy 34, no. 4 (2012): 373-401.

Chan, Anita. "Strikes in China's Export Industries in Comparative Perspective." The China Journal 65 (2011): 27-51.

Chan, Anita China's Workers under Assault. Armonk: M.E. Sharpe, 2001.

Chen, Feng. "Between the State and Labour: The Conflict of Chinese Trade Unions' Double Identity in Market Reform." The China Quarterly (2003): 1006- 28.

- - - "Individual Rights and Collective Rights: Labor's Predicament in China." Communist and Post Communist Studies 40, no. 1 (2007): 59-79.

Chen, Feng "Trade Unions and the Quadripartite Interactions in Strike Settlement in China ". The China Quarterly 102 (2010): 104-24.

China Daily. "About Cpc's Mass Line Campaign." China Daily (19 July 2013).

China Labour Bulletin. "Strike Map." China Labour Bulletin.

- - - "Wages and Employment." China Labour Bulletin (2016).

- - - "Wages in China ". (19 February 2008).

China News Web. "Most Provinces in China Have Already Fundamentally Resolved the Historical Problem of Delayed Payment of Wages." (8 March 2008).

Chou, Yangsun, and Andrew Nathan. "Democratizing Tradition in Taiwan." Asian Survey 27, no. 3 (1987): 277-99.

Chung, Jae Ho, Hongyi Lai, and Ming Xia. "Mounting Challenges to Governance in China: Surveying Collective Protestors, Religions Sects and Criminal Organizations." The China Journal 56 (2006): 1-31.

Cooley, Alexander. "Authoritarianism Goes Global: Countering Democratic Norms." Journal of Democracy 26, no. 3 (2015): 49-63.

Cooney, Sean. "Making Chinese Labor Law Work: The Prospects for Regulatory Innovation in the People's Republic of China." Fordham International Law Journal 30, no. 4 (2007): 1050-97.

Cooney, Sean, Sarah Biddulph, and Ying Zhu. Law and Fair Work in China. London: Routledge, 2013.

Deng, Wei. "Resolving Unpaid Wages by Spring Festival: Mission Impossible? ." People's Daily Online (15 January 2004).

Deng, Xiaoping. "Emancipate the Mind, Seek Truth from Facts and Unite as One in Looking to the Future." In Selected Works of Deng Xiaoping (1975-1982), edited by Lenin Bureau for the Compilation and Translation of Works of Marx, Engels and Stalin under the Central Committee of the Communist Party of China, 151-65. Beijing: Foreign Languages Press, 1978.

_-_. "Uphold the Four Cardinal Principles, 30 March 1979." In Selected Works of Deng Xiaoping (1975-1982), edited by Lenin Bureau for the Compilation and Translation of Works of Marx, Engels and Stalin under the Central Committee of the Communist Party of China, 166-91. Beijing: Foreign Languages Press, 1993.

Ding, Xiaodong. "Law According to the Chinese Communist Party: Constitutionalism and Socialist Rule of Law." Modern China 43, no. 3 (2017): 322-52.

Division(调解仲裁管理司), Mediation and Arbitration Management. "The Responsible Person in the Ministry of Human Resources and Social Security Mediation and Arbitration Management Division Responds to a Journalist's Questions About the 'Opinion on Further Strengthening the Multidisciplinary Mechanism of Mediation and Arbitration of Labor and Personnel Disputes (人 
社部调解仲裁管理司负责人就《关于进一步加强劳动人事争议调解仲裁完善多元处理机制 的意见》答记者问)." (1 April 2017).

Dutton, Michael. "Dreaming of Better Times: 'Repetition with a Difference' and Community Policing in China." positions east asia cultures critique 3, no. 2 (1995): 418-47.

Edin, Maria. "State Capacity and Local Agent Control in China: Ccp Cadre Management from a Township Perspective." The China Quarterly 173 (2003): 35-52.

Friedman, Eli, and Ching Kwan Lee. "Remaking the World of Chinese Labour: A 30 Year Retrospective." British Journal of Industrial Relations 48, no. 3 (2010): 507-33.

General Office of the State Council, (国务院办公厅). "Opinion on Comprehensviely Managing the Problem of Non-Payment of Migrant Workers' Wages (关于全面治理拖欠农民工工资问题的 意见)." (17 January 2016).

Greenfield, Gerard, and Tim Pringle. "The Challenge of Wage Arrears in China." In Paying Attention to Wages, edited by Manuel Simón Velasco. Geneva: International Labour Organisation, 2002.

Halegua, Aaron. "Getting Paid: Processing the Labor Disputes of China's Migrant Workers." Berkeley Journal of International Law 26, no. 1 (2008): 254-322.

- - - "Who Will Represent China's Workers? Lawyers, Legal Aid and the Enforcement of Labor Rights." New York University School of Law U.S., Asia Law Institute (October 2016).

$\mathrm{He}$, Xin. "Sporadic Campaigns as a Means of Social Control." Columbia Journal of Asian Law 17, no. 1 (2003): 121-45.

Heilmann, Sebastian, and Elizabeth Perry, eds. Mao's Invisible Hand: The Political Foundations of Adaptive Governance in China. Cambridge (Mass) and London: Harvard University Press, 2011.

Ho, Virginia "From Contracts to Compliance? An Early Look at Implementation under China's New Labor Legislation ". Columbia Journal of Asian Law 23, no. 1 (2009): 35-107.

Howland, Douglas. "Popular Sovereignty and Democratic Centralism in the People's Republic of China ". Social Text 30, no. 1 (2012): 1-25.

Inner Mongolia Autonomous Region Office of Human Resources and Social Security, 内蒙古自治区自治 区人力资源和社会保障厅 "Autonomous Region Undertakes Construction of Harmonious Labour Relations Propaganda Month Activities 自治区开展构建和谐劳动关系宣传月活动." Inner Mongolia Austnomous Region Human Resources and Social Security Web (8 July 2015).

Jiang, Shigong. "Written and Unwritten Constitutions: A New Approach to the Study of Constitutional Government in China." Modern China 36 (2010): 12-46.

Lam, Willy Wo-Lap. "China's Anti-Graft Campaign in Review." China Brief 15, no. 23 (7 December 2015): 3-6.

Landry, Pierre, Yanqi Tong, and Mingming Shen. "Introduction: Markets, Courts and Leninism." The China Review 9, no. 1 (2009): 1-16.

Lee, Ching Kwan. Against the Law: Labor Protests in China's Rustbelt and Sunbelt. Berkeley: University of California Press, 2007.

Lee, Ching Kwan, and Yonghong Zhang. "The Power of Instability: Unraveling the Microfoundations of Bargained Authoritarianism in China." American Journal of Sociology 118, no. 6 (2013): 1475508.

Lee, Sangkuk. "An Institutional Analysis of Xi Jinping's Centralization of Power." Journal of Contemporary China 26, no. 105 (2017): 325-36.

Li, Ling. "'Rule of Law" in a Party-State: A Conceptual Interpretive Framework of the Constitutional Reality of China." Asian Journal of Law and Society 2, no. 1 (2015): 93-113.

$\mathrm{Li}$, Wei. "How to Prevent and Control the Masses Engaging in Collective Petitioning (Ruhe Yufang He Kongzhi Qunzong Jiti Shangfang)." The Secretary's Friend (Mishu zhi You), no. 3 (1999): 34-35.

Ma, Ling 马岭. "The Principle of Democratic Centralism in China's Current Constitution (Woguo Xianxing 'Xianfa" Zhong De Minzhu Jizhong Yuanze 我国现行《宪法》中的民主集中制原则)." Journal of Yunnan University, Law edition (Yunnan Daxue Xuebao Faxue Ban 云南大学学报法学版) 26, no. 4 (2013): 2-14. 
McFarquhar, Roderick, and John K Fairbank, eds. Cambridge History of China Vol. 15 Part 2. Cambridge: Cambridge University Press, 1991.

Milhaupt, Curtis, and Katarina Pistor. Law and Capitalism: What Corporate Crises Reveal About Legal Systems and Economic Development around the World. Chicago: Chicago University Press, 2008.

Ministry of Human Resources and Social Security. "Second Plenary Meeting of the Inter-Ministerial Joint Meeting on Efforts to Resolve the Problem of Wage Arrears (解决企业拖欠工资问题部际联席 会议第二次全体会议召开)." (15 March 2017).

NPC Standing Committee. "Npc Standing Committee Law Enforcement Investigation Group 'Report on the Implementation of the Prc Construction Law' (Quanguo Renda Changweihui Zhifa Jiancha Zu Guanyu Jiancha "'Zhonghua Renmin Gongheguo Jianzhu Fa' Shishi Qingkuang De Baogao') ". China Construction Information Web (6 November 2003).

Peerenboom, Randall. China's Long March toward Rule of Law. Cambridge: Cambridge University Press, 2002.

Peng, Zhen. "The Hard Strike against Crime Must Abide by the Law, Pay Attention to Policy and Strengthen Comprehensive Management." edited by National Conference of Public Security Office and Division Heads, 15-22 November 1983.

People's Daily Online. "The State Council Deploys to Rectify the Delayed Payment of Construction Funds in the Construction Sector: Zeng Peiyan Emphasises That before Spring Festival Each Region Must Pay Close Attention to Payment of Migrant Workers Unpaid Wages from the Previous Year." (3 January 2004).

Pun, Ngai, and Huilin Lu. "A Culture of Violence: The Labor Subcontracting System and Collective Action by Construction Workers in Post-Socialist China." The China Journal 64 (2010): 143-58.

Sapio, Flora. "Seeking Truth from Facts in Party Discipline Legislation "In 10th Annual conference of the European China Law Studies Association. Cologne, 25-27 September 2015.

Strauss, Julia. "Morality, Coercion and State Building by Campaign in the Early Prc; Regime Consolidation and after, 1949-1956." The China Quarterly 188 (2006): 891-912.

Su, Yang , and Xin He. "Street as Courtroom: State Accommodation of Labour Protest in South China." Law \& Society Review 44, no. 1 (2010): 157-84.

Sun, Shengfu. "Guanyu Jianchi 'Yanda' Fanzhen De Yixie Sikao (Some Reflections on Upholding the Guiding Principle of the 'Hard Strike' )." In Zhongguo Renmin Gong'an Daxue Xiaoqing Shi Zhou Nian Lunwen Xuanji (Selection of Essays for the Tenth Anniversary of the China People's Public Security University), 248-54. Beijing: Zhongguo Renmin Gongan Daxue Chubanshe (China People's Public Security University Press), 1994.

Sun, Wanning. "Desperately Seeking My Wages: Justice, Media Logic, and the Politics of Voice in Urban China." Media, Culture and Society 37, no. 4 (2012): 864-79.

Sun, Xingwei 孙兴伟. "Work to Ensure That the Wages Migrant Workers Should Receive Are Paid on Time and in Full（确保农民工按时足额拿到英得工资）." China Labour Protection Daily (中国 劳动保障报) (21 November 2015).

Tanner, Murray Scot. "State Coercion and the Balance of Awe: The 1983-1986 "Stern Blows" Anti Crime Campaign." The China Journal 44 (2000): 93-125.

Tay, Alice, and Eugene Kamenka. "Marxism, Socialism and the Theory of Law." Columbia Journal of Transnational Law 23 (1984-1985): 217-49.

Trevaskes, Susan. "Severe and Swift Justice in China." British Journal of Criminology 47 (2007): 23- 41.

- - - "Yanda 2001: Form and Strategy in a Chinese Anti-Crime Campaign." Australian and New Zealand Journal of Criminology 36, no. 3 (2003): 272-92.

van Rooij, Benjamin. "The Politics of Law in China: Enforcement Campaigns in the Post-Mao Prc." http://ssrn.com/abstract=136181. (2009).

- - . "Regulation by Escalation: Unrest, Lawmaking and Law Enforcement in China." Chap. 5 In The Politics of Law and Stability in China, edited by Susan Trevaskes, Elisa Nesossi, Flora Sapio and Sarah Biddulph, 83-106. Cheltenham: Edward Elgar Publishing. 
Wang, Chuanzhi. "Democratic Centralism: The Core Mechanism in China's Political System." Qiushi Journal (English edition) 5, no. 4 (4 October 2013).

Whiting, Susan. "Authoritarian "Rule of Law" and Regime Legitimacy." Comparative Political Studies (2017): 1-34.

Xinhua News Agency. "Resolving Delayed Payment of Wages in the Construction Sector: 5 Trump Cards in Blocking Off the Deadbeats'usual Escape Routes." (16 December 2003).

Xiong, Xianguo. "Yifa "Yanda" ("Strike Hard" According to the Law)." Renmin Fayuan Bao (People's Court Daily), 2001.

Zhang, Yujie 张玉洁. "Mohrss Convenes the 2016 Annual Work Meeting on Ensuring Payment of Migrant Workers' Wages Prior to Spring Festival 人社部召开 2016 年春节前保障农民工工资 支付工作视会." China Organisations and Personnel Daily 中国组织人事报 (23 November 2015).

Zhao, Jiaxin 赵家新. "Xinghua: Create a Foundation for Stability Let the Masses, Stably Enjoy Peace 兴 化：稳定根基让群众 “稳” 享平安." People's Police Daily 人民公安报 (3 February 2016). 


\section{University Library}

\section{- M M N E R VA A gateway to Melbourne's research publications}

Minerva Access is the Institutional Repository of The University of Melbourne

Author/s:

Biddulph, S

Title:

Democratic Centralism and Administration in China

Date:

2018

Citation:

Biddulph, S. (2018). Democratic Centralism and Administration in China. Hualing, F (Ed.). Gillespie, J (Ed.). Nicholson, P (Ed.). Partlett, W (Ed.). Socialist Law in Socialist East Asia, Socialist Law in Socialist East Asia, (1), pp.195-223. Cambridge University Press.

Persistent Link:

http://hdl.handle.net/11343/254293 